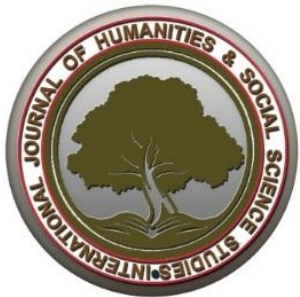

International Journal of Humanities \& Social Science Studies (IJHSSS)

A Peer-Reviewed Bi-monthly Bi-lingual Research Journal

ISSN: 2349-6959 (Online), ISSN: 2349-6711 (Print)

Volume-I, Issue-III, November 2014, Page No. 261-265

Published by Scholar Publications, Karimganj, Assam, India, 788711

Website: http://www.ijhsss.com

\title{
Awareness Regarding HIV among Male Sex Workers in Larkana City
} Muhammad Abdullah Avais

Ph. D Scholar, University of Sindh, Jamshoro Pakistan

\author{
Dr. Aijaz Ali Wassan
}

Associate Professor Dept. of Sociology University of Sindh Jamshoro, Pakistan

\section{Dr. Rafique Ahmed Chandio}

Assistant Professor Department of Economics University of Sindh, Jamshoro, Pakistan

Ms. Najma Shaikh

Assistant Professor Dept. of Economics University of Sindh, Jamshoro, Pakistan

\section{Abstract}

The objective of this study is to describe the knowledge of HIV/Aids and risky behavior of male sex workers (MSWs) in Larkana city, Pakistan. This is an exploratory research based on primary data. The data have been sampled through snow ball sampling method. Numerous sexual partners, un protected anal intercourse and sexual relations with drug addicts (Intra Venus drug users) put MSWs on increasing risk of sexually transmitted diseases (STDs) and HIV/Aids infection. Results show that $86 \%$ MSWs had sexual relations with drug users and 54\% had unprotected sex in last month. Only $46 \%$ respondents aware regarding HIV/Aids and 35\% know the center where they can get clinical HIV test and $0 \%$ respondents have undergone any medical/HIV test.

Key Words: Safe Sex, Male Sex Workers, Prostitution, Larkana City, Islamic Republic of Pakistan

Introduction: Commercial sex work is a basic feature of homosexual men in his sexual life. Since 1947, Pakistan has been trying to stable its foreign exchange. Due to political destabilization, country's economic growth was badly suffered. People involve in low cost sex likewise male with male etc due to economic instability. Pakistan is an Islamic state according to constitution, where law or culture, custom can integrate religion in all codes and values. Sex without marriage, including homosexual relations are still taboos in Pakistan (Shafique, 2006) ${ }^{1}$. Under the umbrella of Islam any kind of sexual relation excluding marital relations are haram (Strictly forbidden). Therefore most people believe that HIV/Aids through illicit sexual relations are not problem of Muslim world (Osteria, 1991) $)^{2}$. While scenario is different on ground level. In Pakistan ratio of HIV/Aids infected men is seven time higher than women (Rajab et al. 2008) ${ }^{3}$. Olaleye $(2003)^{4}$ describes that, Acquired Immune Deficiency Syndrome (AIDS) is a viral infection caused by Human Immunodeficiency Virus (HIV). This virus usually found in body fluid (blood, semen, vaginal fluid and breast milk) of infected person. This virus can be transferred from infected person to healthy person through unprotected sexual intercourse and sharing of un sterilized medical instruments or infected shaving kits. Near the railway station of Larkana, in the middle of city, various hotels, motels and tea stalls are available for passengers as well as local community. Here people can hire one small bed room and bath room on cheap price. These type of hotels call "MusafirKhana" (Altaf, 2012) ${ }^{5}$. These hotels are popular for male sex workers (Male Prostitutes). MSWs hire a number of rooms in these hotels and clients visit them all the day for anal or oral sex. These male prostitutes are high vulnerable group to HIV. These MSWs exchange sex for money and some time they involve in un safe sex on demand of client. Most of the clients are gay or bisexual male and some of them have female sex partners (Mores et al. 1991) ${ }^{6}$. Male prostitutes charge Pak. Rs: $150-250$ per one sexual interval according to satisfaction of client (Avais, 2014). While un skilled worker earn hardly Pk. Rs: 250 - 350 after all day (minimum 08 hours) work. Logon $(2013)^{7}$ identified that market features of male sex workers are unrevealed. Usually people assume that male prostitution is a moral issue and it is associated with deviation of 

gander (Scott et al., 2005) ${ }^{8}$. Male sex workers have very little existence in sex industry. As compare to female sex workers, MSWs work independently. A lot of quantitative work available on female sex workers (Lillard, 1998) ${ }^{9}$. Very limited work on male sex worker is available in developing countries (Shah, 2013) ${ }^{10}$ especially in Pakistan due to high moral and religious restrictions. In 2012, 27.7\% out of 100 HIV reported cases belonged to Larkana and in first seven month of 2013, $45.1 \%$ out of 100 HIV positive patients belonged to $15-25$ years age group \& $39.7 \%$ reported cases belonged to Larkana (Memon, 2014) ${ }^{11}$ and It is estimated that there are 1,698 male \& hijra sex workers available for paid sex in Larkana. Halkities et al. (2004) argued that male sex workers have higher risk of sexually transmitted diseases (STD), including HIV.

Literature Review: There is not been much research literature available on the perception, attitude and awareness of MSWs regarding HIV/Aids. It is noted that education may change the attitudes and can increase level of realistic knowledge in sexual practice (Grunseit, 1998) ${ }^{12}$. Khan (2009) ${ }^{13}$ argued that data on structural or social drivers of HIV/Aids risk among MSWs in Pakistan is scare. Caceres, $(2006)^{14}$ noted that $5 \%$ to $10 \%$ HIV/Aids infections in world are transmitted through unprotected sex between male and male. Unprotected anal intercourse is main route of HIV/Aids transmission in MSWs (Herbert et al., 2005) ${ }^{15}$. Johnson et al. $(2008)^{16}$ argued that behavioral interventions can reduce unprotected sex among MSWs.

Locale: Larkana city is situated on right bank river Indus. According to population welfare department in 2010 the total population of district is around 1.4 million while population of Larkana city is 539,075 (Memon et al. 2014) ${ }^{17}$.

Objectives: The main objective of the study is to find out awareness regarding HIV/Aids in MSWs and sexual behavior of MSWs.

Research Methodology: This is an exploratory research based on primary data. The data has been sampled through snow ball sampling method. 37 male prostitutes were selected from Larkana city. In depth interviews were conducted. Clients of all the respondents are male. The male prostitutes those serve for female are not included in this research.

\section{Results:}

Table I

Analysis the risk factors of HIV among Male Sex Workers in Larkana $(\mathrm{N}=27)$

\begin{tabular}{|c|c|}
\hline Do you Know regarding HIV/Aids? & Responses \\
\hline Yes & $46 \%$ \\
\hline No & $54 \%$ \\
\hline \multicolumn{2}{|l|}{ Current Living Status } \\
\hline Friends & $24 \%$ \\
\hline Alone & $57 \%$ \\
\hline Family & $19 \%$ \\
\hline \multicolumn{2}{|l|}{ Duration in Sex Work (Years) } \\
\hline $02<$ & $27 \%$ \\
\hline $2.1-04$ & $70 \%$ \\
\hline $4.1>$ & $3 \%$ \\
\hline \multicolumn{2}{|l|}{ Age at 1st sexual interval (years) } \\
\hline 08 to 15 & $84 \%$ \\
\hline 15 to 20 & $11 \%$ \\
\hline $20>$ & $5 \%$ \\
\hline \multicolumn{2}{|c|}{ Sexual interval without condom in last 01 month } \\
\hline Yes & $54 \%$ \\
\hline No & $46 \%$ \\
\hline \multicolumn{2}{|l|}{ Have you condom now? } \\
\hline Yes & $22 \%$ \\
\hline No & $78 \%$ \\
\hline
\end{tabular}

Source: Primary Data 
Analyses of Data: The result indicates that $46 \%$ male sex workers (MSWs) know regarding HIV/Aids and majority of the respondents $54 \%$ don't know regarding HIV/Aids. Unawareness is itself very dangerous for MSWs. Due to unawareness MSWs involve in unprotected sex and they are more prone to be infected by HIV. Moreover long involvement in sexual activities and involvement in sex during teen age can become causes of HIV/Aids infection in MSWs. 57\% MSWs live alone and they are easily available for sexual satisfaction in day or night. 24\% MSWs lives with their friends. These friends may be their permanent customers or group of other MSWs. Only 19\% MSWs live with their families. $78 \%$ respondents had not condom at the time of interview and 54\% respondents had unsafe sexual relation with in last month. While $46 \%$ respondents had not unsafe sex with in last month and $22 \%$ respondents had condom at the time of interview. Multiple partners increase risk of HIV/Aids in homosexual population. It is noted that MSWs are involved in spreading of HIV Infection (Halkitis et al., 2004) ${ }^{18}$. Respondents believe that HIV/Aids spread through, un safe sex with male $56 \%$, through dentist $57 \%$, through re used syringes $65 \%$, un safe sex with female $81 \%$, through tattoos on body $24 \%$ and staying filthy $51 \% .86 \%$ respondents have had sexual intercourse with drug addicts in last month. $65 \%$ respondents don't know regarding where about of government/ medical health center there they can go for treatment in case of STD or HIV screening. 100\% respondents never gone through HIV screening test. $78 \%$ respondents self-medicate in case of illness while $22 \%$ visit the doctor either qualified or quake.

Table I Analysis the risk factors of HIV among Male Sex Workers in Larkana ( $=27)$

\begin{tabular}{|c|c|}
\hline \multirow{2}{*}{$\begin{array}{c}\text { Knowledge regarding spread of HIV/Aids } \\
\text { Un safe Sexual Intercourse with Male }\end{array}$} & \multirow{2}{*}{ Responses } \\
\hline & \\
\hline Yes & $46 \%$ \\
\hline No & $54 \%$ \\
\hline \multicolumn{2}{|l|}{ Through Dentist } \\
\hline Yes & $57 \%$ \\
\hline No & $43 \%$ \\
\hline \multicolumn{2}{|l|}{ Through re used syringe } \\
\hline Yes & $65 \%$ \\
\hline No & $35 \%$ \\
\hline \multicolumn{2}{|l|}{ Un Safe Sexual Intercourse with Female } \\
\hline Yes & $81 \%$ \\
\hline No & $19 \%$ \\
\hline \multicolumn{2}{|l|}{ Through Tattos } \\
\hline Yes & $24 \%$ \\
\hline No & $76 \%$ \\
\hline \multicolumn{2}{|l|}{ Through staying filthy } \\
\hline Yes & $51 \%$ \\
\hline No & $49 \%$ \\
\hline \multicolumn{2}{|c|}{ Sexual interval with drug addict (Injection user) in last month } \\
\hline Yes & $86 \%$ \\
\hline No & $14 \%$ \\
\hline \multicolumn{2}{|c|}{ Do you know government lab Where people go for HIV test? } \\
\hline Yes & $35 \%$ \\
\hline No & $65 \%$ \\
\hline \multicolumn{2}{|l|}{ Treatment of Infections } \\
\hline Self-Medications & $78 \%$ \\
\hline Visit Doctor & $22 \%$ \\
\hline \multicolumn{2}{|l|}{ Ever Tested for HIV } \\
\hline Yes & $0 \%$ \\
\hline No & $100 \%$ \\
\hline
\end{tabular}


Source: Primary Data

Conclusion: The study was conducted under many limitations. The data was collected from small sample and cannot be generalized to whole Larkana city. The interview were conducted through snowball sampling technique. The MSWs those serve to women are not part of this study. It must be noted that prostitution itself is strictly banned in Islam. Therefore data is self-reported by MSWs on very sensitive topic and not easy to verify. The data indicates that a high active community of MSWs \& clients of MSWs are present in study area. MSWs have little knowledge regarding HIV/Aids. Multiple sexual partners put the MSWs at high risk of STDs and HIV/Aids infection. Condom use is low and they are habitual to self-medicate. Therefore these MSWs may cause of spread of infections due to travel to other parts of Sindh as well as Pakistan. Government as well as NGOs are running many HIV awareness programmes in Sindh but the ground situation is very different.

Suggestions: Health care services must be developed on ground level and they must be advertised. These facilities must be available near to the sites where sex workers and clients meet. Increasing knowledge of HIV/Aids may impose positive effect and build safe \& HIV/Aids free environment in community.

\section{References:}

1. Shafiq M, Ali SH. (2006). Sexually transmitted infections in Pakistan. Lancet Infect Dis: 6: 321-22.

2. Osteria T, Sullivan G. (1991). The impact of religion and cultural values on AIDS education programs in Malaysia and the Philippines. AIDS Educ Prev; 3: 133-46.

3. Rajabali, A., Khan, S., Warraich, H. J., Khanani, M. R., \& Ali, S. H. (2008). HIV and homosexuality in Pakistan. The Lancet Infectious Diseases, 8(8), 511-515.

4. Olaleye, R.S. (2003). Level of HIV/aIDS Awareness among rural farmers and its implication for food security in Ondo State, Nigeria. International Journal of Gender and Heath Studies $1(1): 16-21$.

5. Altaf, A., Zahidie, A., \& Agha, A. (2012). Comparing risk factors of HIV among hijra sex workers in Larkana and other cities of Pakistan: an analytical cross sectional study. BMC public health, 12(1), 279.

6. Morse E, Simon P, Osofsky H, Balson P, Gaumer H. (1991). The male street prostitute: a vector for transmission of HIV infection into the heterosexual world. Soc Sci Med 5:535-539.

7. Logan, T. D. and M. Shah (2013). "Face Value: Information and Signaling in an Illegal Market." Southern Economic Journal 79 (3): 529-564.

8. Scott, J., Minichiello, V., Marino, R., Harvey, G. P., Jamieson, M., \& Browne, J. (2005). Understanding the new context of the male sex work industry. J Interpers Violence, 20(3), 320342.

9. Lillard, L. A. (1998). .The Market for Sex: Street Prostitution in Los Angeles Paper presented at the 1999 Population Association of America Annual Meetings.

10. Shah, M. (2013). "Do Sex Workers Respond to Disease? Evidence from the Male Market for Sex." American Economic Review Papers and Proceedings. 103 (3): 445-450.

11. Memon, A., Haider, S., \& Altaf, A. (2014). Alarming increase in reported HIV cases from Larkana, Pakistan: a matter of serious concern. J Pak Med Assoc, 64(2), 205-206.

12. Grunseit, AC \& Aggleton. P. (1998). Lessons learned: an update on the published literature concerning the impact of HIV and sexuality education for young people. Health Education. Mar. (2): 45-54.

13. Khan, F. H. (2009). "HIV and Homosexuality in Pakistan." Lancet Infectious Diseases 9 (4): 204-205.

14. C Cáceres, K Konda, M Pecheny. (2006). A Chatterjee and R Lyerla. Estimating the number of men who have sex with men in low and middle income countries. Sexually Transmitted Infections; 82(suppl_3):3-9 
15. Herbst JH, Sherba TR, Crepaz JB, DeLuca J, Zohrabyan L, Stall R, et al.(2005). A metaanalytic review of HIV behavioral interventions for reducing sexual risk behavior of men who have sex with men (MSM). J Acquir Immune Defic Syndr; 39:228-241.

16. Johnson WD, Diaz RM, Flanders WD, Goodman M, Hill A, Holtgrave D, et al. (2008). Behavioral interventions to reduce risk for sexual transmission of HIV among men who have sex with men. Cochrane Database Syst Rev: CD 001230.

17. Memon, A., Haider, S., \& Altaf, A. (2014). Alarming increase in reported HIV cases from Larkana, Pakistan: a matter of serious concern. J Pak Med Assoc, 64(2), 205-206.

18. Halkitis, P. N., et al. (2004). .Gay and Bisexual Male Escorts who advertise on the Internet: Understanding Reasons for and Effects of Involvement in Commercial Sex. International Journal of Men.s Health 3:11-26.

$* * * * *$ 